\title{
Coriander Aphid, Hyadaphis coriandri (Das) (Insecta: Hemiptera: Aphididae) ${ }^{1}$
}

Susan E. Halbert ${ }^{2}$

\section{Introduction}

The coriander aphid, Hyadaphis coriandri (Das), was found for the first time in North America on fennel (Foeniculum vulgare Mill.) at Orange County residences in Apopka and Orlando. In December 1998, an infestation also was found on coriander (Coriandrum sativum Linnaeus) and dill (Anethum graveolens Linnaeus) at a residence in Tampa, Hillsborough County.

There are about thirteen described species of Hyadaphis (Remaudière and Remaudière 1997), most of which are obscure Central Asian or European species (Ivanovskaya 1977, Kadyrbekov 1990, Miyazaki 1971, Raychaudhuri et al. 1980, Shaposhnikov 1964). There are several species in the genus known to be pests, including the coriander aphid, Hyadaphis foeniculi (Passerini), Hyadaphis passeriniii (del Guercio) and Hyadaphis tataricae (Aizenberg).

Only three Hyadaphis species occur in the Western Hemisphere. Hyadaphis foeniculi, the honeysuckle aphid, has been in North America for a long time. Its winter host is honeysuckle, and summer hosts are various Umbelliferae including some cultivated crops. There are no Division of Plant Industry specimens or records of this species in Florida.

Hyadaphis tataricae, the honeysuckle witches' broom aphid, was introduced into the Western Hemisphere in the mid 1970s and had colonized northern USA and southern Canada within about ten years. It apparently is restricted to northern states (Voegtlin 1988). The honeysuckle witches' broom aphid completes its entire life cycle on honeysuckle, to which it causes major damage in North America. The coriander aphid has been found only in Florida and California.

\section{Distribution}

Coriander aphids probably are native to Central Asia, where they have been found on their primary host plants. Current worldwide distribution includes Central Asia, the Mediterranean area, the Indian Subcontinent, Africa, and California and Florida in the United States.

1. This document is EENY-296 (originally published as DPI Entomology Circular 399), one of a series of Featured Creatures from the Entomology and Nematology Department, Florida Cooperative Extension Service, Institute of Food and Agricultural Sciences, University of Florida. Published: June 2003. This document is also available on Featured Creatures Website at http://creatures.ifas.ufl.edu. Please visit the EDIS Website at http://edis.ifas.ufl.edu. Additional information on these organisms, including many color photographs, is available at the Entomology and Nematology Department website at http://entnemdept.ifas.ufl.edu/.

2. Susan E. Halbert, Florida Department of Agriculture and Consumer Services, Division of Plant Industry, Gainesville, FL.

The Institute of Food and Agricultural Sciences (IFAS) is an Equal Employment Opportunity - Affirmative Action Employer authorized to provide research, educational information and other services only to individuals and institutions that function without regard to race, creed, color, religion, age, disability, sex, sexual orientation, marital status, national origin, political opinions or affiliations. For information on obtaining other extension publications, contact your county Cooperative Extension Service office. Florida Cooperative Extension Service / Institute of Food and Agricultural Sciences / University of Florida / Larry R. Arrington, Interim Dean 


\section{Description}

Coriander aphids are yellow-green in color, dusted with greyish wax. They have short, dusky, slightly swollen, siphunculi (or cornicles) that are about twice as long as wide. They form dense and often damaging colonies on leaves, heads, and stems of their host plants. In Florida, several other species colonize the common hosts of the coriander aphid. These include various Aphis spp., the green peach aphid (Myzus persicae (Sulzer)), and the rice root aphid (Rhopalosiphum rufiabdominalis (Sasaki). Both green peach aphids and the Aphis spp. have siphunculi that are much longer than twice their diameter. Rice root aphids live underground.

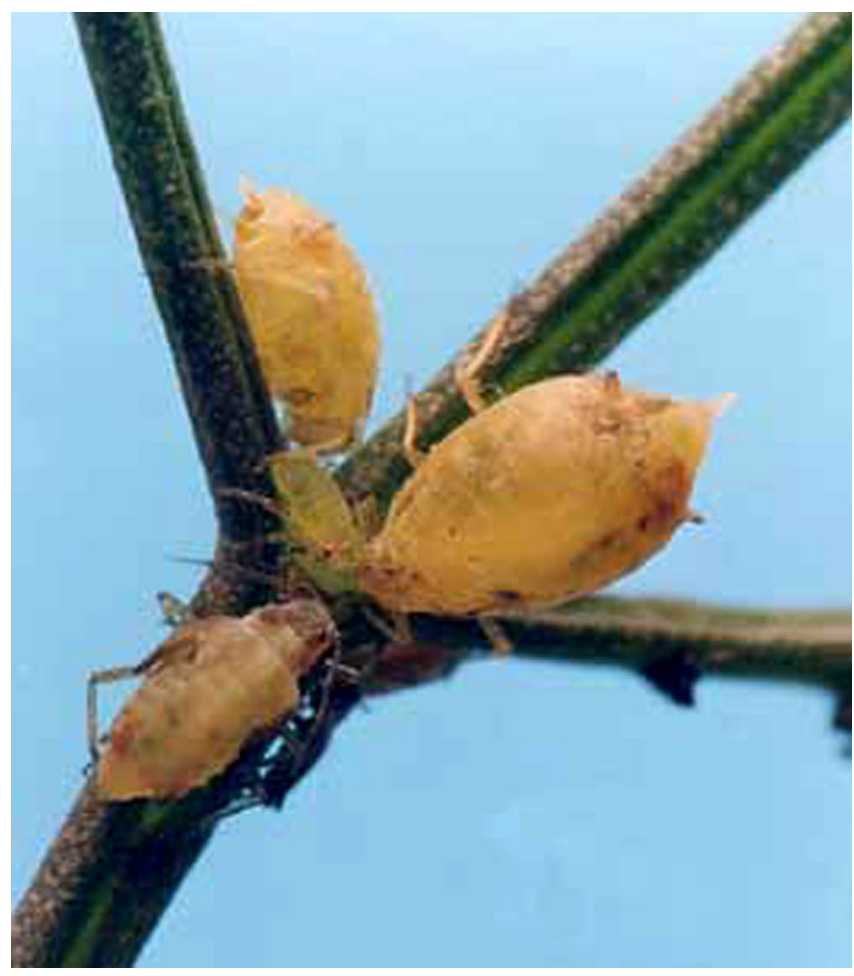

Figure 1. Colony of coriander aphids, Hyadaphis coriandri (Das), on fennel. Credits: Jeffrey Lotz, Division of Plant Industry

\section{Life History}

In its native land of Central Asia, the life cycle of the coriander aphid is similar to that of other host-alternating aphids. Overwintering eggs occur on Lonicera nummulariifolia Jaub. \& Spach. and other Lonicera spp. (Remaudière and Halbert 2000). A fundatrix (or stem mother) hatches from the egg in the spring. Her offspring are parthenogenetic, winged-female spring migrants. They colonize summer host plants in the family Umbelliferae. During the summer, there are many generations of aphids. All individuals are parthenogenetic females, but they can be either winged or wingless, depending on host plant quality and crowding in the colony. If host plant quality declines, or the colony becomes crowded, winged individuals form that can establish colonies on new plants.

In the autumn, parthenogenetic female fall migrants occur in response to cooler temperatures and/or short days. These return to the winter hosts, where they give birth to egg-laying females. Similarly, the summer colonies produce winged males in the fall. The males also return to the winter host plants, where they mate with the egg-laying females to produce the overwintering eggs.

In Florida, the overwintering part of the life cycle probably will not occur. More likely, colonies of summer forms, both winged and wingless, will persist on Umbelliferae throughout the year.

\section{Hosts}

Species of Hyadaphis are associated with Caprifoliaceae (winter hosts) and/or Umbelliferae (summer hosts). The coriander aphid has been found in Florida only on its summer host plants. Florida hosts to date include coriander, dill, fennel and parsley (Petroselinum crispum (P. Mill.) Nyman ex A.W. Hill). Other reported hosts include celery (Apium graveolens Linnaeus var. dulce (Miller) DC.) and carrots (Daucus carota Linnaeus var. sativus Hoffm.). There are records of sporadic colonies on miscellaneous hosts outside the Umbelliferae, including horsemint (Mentha longifolia (Linnaeus) Huds.), spiny pigweed (Amaranthus spinosus Linnaeus), soybean (Glycine max (Linnaeus) Merr.), and blond psyllium (Plantago ovata Forssk.) (Blackman and Eastop 1984, Kumar and Sagar 1994). The coriander aphid is considered a key pest of coriander in India in the spring (Kumar and Sagar 1994).

\section{Survey and Detection}

The best way to find coriander aphids is to inspect their common host plants, including coriander, dill, fennel, parsley, and other 


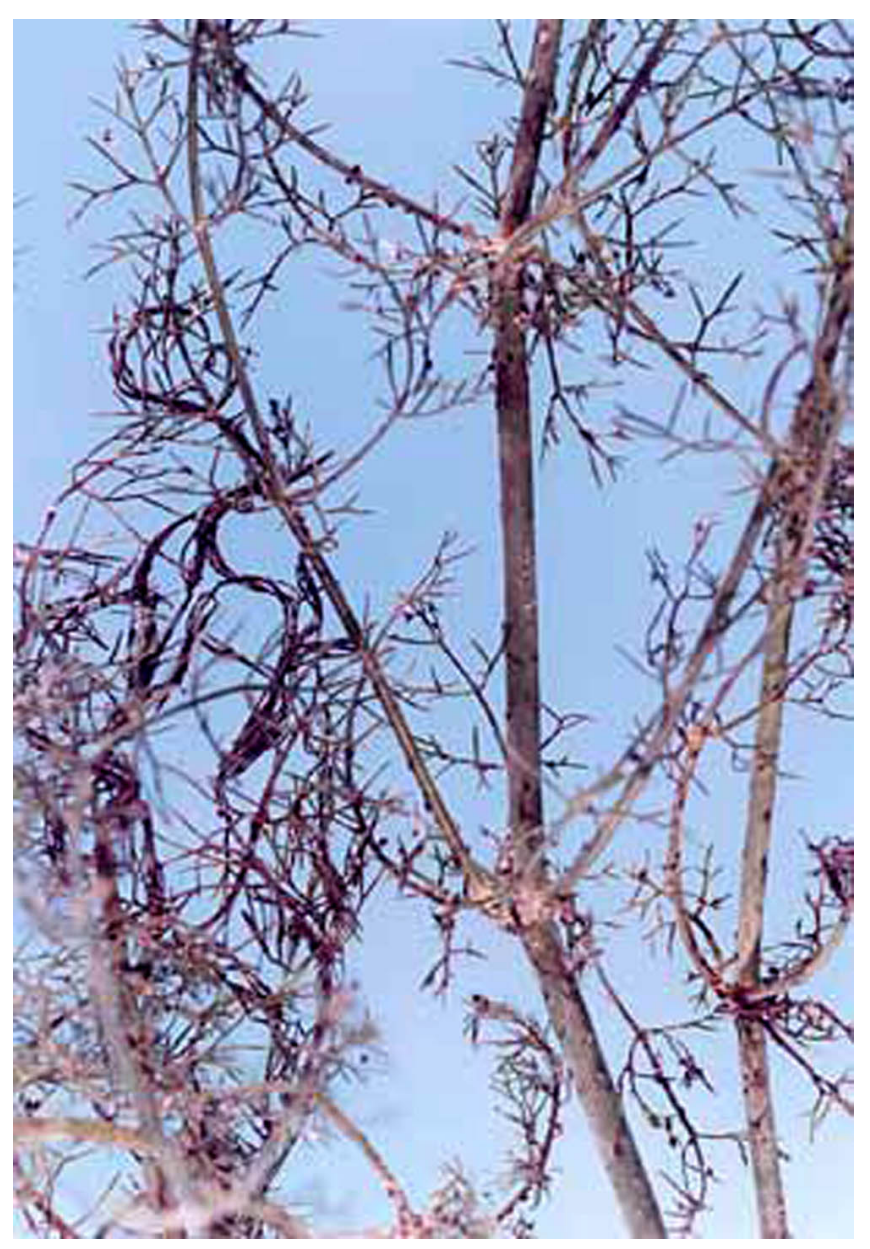

Figure 2. Damage to fennel by coriander aphids, Hyadaphis coriandri (Das). Credits: Jeffrey Lotz, Division of Plant Industry

Umbelliferae. There is a danger that coriander aphids could be distributed widely if they became established in nurseries that produce small pots of herbs for supermarkets, so these types of businesses would be a priority for inspection.

\section{Management}

Consult with local University of Florida extension personnel for control of coriander aphids. Available materials may be limited because the host plants of coriander aphids are minor crops. For advice on chemical, cultural and biological controls see: Insect Management Guide for Celery and Parsley (http://edis.ifas.ufl.edu/IG149).

\section{Selected References}

Blackman RL, Eastop VF. 1984. Aphids on the World's Crops. J. Wiley and Sons, Chichester. 466 p.
Ivanovskaya OI. 1977. [Aphids of western Siberia], Volume II. Novosibirsk. (In Russian). 328 p.

Kadyrbekov RX. 1990. [Aphid fauna of trees in natural ecosystems of southeastern Kazakhstan]. Kazakhstan Academy of Sciences, Institute of Zoology, Almaty. 38 p.

Kumar N, Sagar P. 1994. Seasonal history and host range of the coriander aphid, Hyadaphis coriandri (Das). Journal of Research, Punjab Agricultural University 31: 283-284.

Miyazaki M. 1971. A revision of the tribe Macrosiphini of Japan (Homoptera: Aphididae, Aphidinae). Insecta Matsumurana 34: 1-247.

Raychaudhure DN, Ghosh AK, Basu RC, Ghosh MR, Chatterjee M, Chakrabarti S, Pal PK. 1980. Aphids of North-east India and Bhutan. The Zoological Society, Calcutta. 521 p.

Remaudière G, Halbert SE. 2000. Hyadaphis coriandri (Das), espèce hètèroecique distincte de $\mathrm{H}$. tataricae (Aizenberg) [Hemiptera, Aphididae]. Ann. Soc. Entomol. Fr. 36: 157-163.

Remaudière G, Remaudière M. 1997. Catalogue des Aphididae du Monde. INRA. Versailles. 478 p.

Shaposhnikov, G CH. 1964. Suborder Aphidinea, pp. 616-799. In G. Ya. Bei-Bienko [ed.], Keys to the insects of the European USSR Vol. I Apterygota, Palaeoptera, Hemimetabola. Israel Program for Scientific Translations, Jerusalem.

Voegtlin DJ. 1988. Hyadaphis tataricae (Homoptera: Aphididae): 10 years after its introduction into North America. Proceedings of the Entomological Society of Washington 90: 256-257 